\title{
The effects of FSH and of testosterone on the completion of meiosis and the very early steps of spermiogenesis of the rat: an in vitro study
}

\author{
M Vigier, M Weiss, M H Perrard, M Godet and P Durand \\ UMR INSERM 418/INRA 1245/Université Claude-Bernard Lyon 1, Hôpital Debrousse, 29 Rue Soeur Bouvier, 69322 Lyon Cedex 05, France
}

(Requests for offprints should be addressed to Philippe Durand; Email: durand@lyon.inserm.fr)

\begin{abstract}
The role of FSH and of testosterone in spermatogenesis has been a matter of controversy. In the present study, we addressed the involvement of these hormones in the regulation of the completion of meiosis of male rats under in vitro conditions. In the first series of experiments, middle/late pachytene spermatocytes were cocultured with Sertoli cells for 2 weeks in the absence or presence of $\mathrm{FSH}$ and/or testosterone. Treatment with both FSH and testosterone reduced slightly the percentage of apoptotic germinal cells in the cultures. Moreover, the number of round spermatids formed in vitro was enhanced by FSH or testosterone when compared with control cultures. Neither hormone influenced the half-life of round spermatids under the present culture conditions. The amounts of TP1 mRNAs in FSH- or FSH plus testosterone-treated cultures were higher than those of controls. In another series of experiments, round spermatids were incubated for $24 \mathrm{~h}$ in media conditioned by Sertoli cells cultured in the absence or presence of FSH and/or testosterone. TP1 mRNA contents of round spermatids incubated in media from Sertoli cells cultured in the presence of $\mathrm{FSH}$ and/or testosterone were two- to threefold higher than those of spermatids incubated in media from Sertoli cells cultured without hormones. These results indicate that FSH and testosterone have positive and somewhat overlapping effects on the meiotic divisions and the post-meiotic expression of a germ cell-specific gene, effects which cannot be related solely to their ability to reduce germinal cell apoptosis. Use of this culture system should help to test the effect of any hormone or factor on those steps in order to understand better their regulation.
\end{abstract}

Journal of Molecular Endocrinology (2004) 33, 729-742

\section{Introduction}

The role of follicle-stimulating hormone (FSH) and testosterone in spermatogenesis has been the subject of numerous studies and controversies for several decades (Sharpe 1994, McLachlan et al. 2002). Indeed, what would seem to be a relatively simple question to answer has remained unclear. The elucidation of the role of each hormone in vivo requires perturbation of the system by a variety of experimental conditions: hypophysectomy (Ahmad et al. 1975, Russell et al. 1987), treatment with a gonadotropin-releasing hormone $(\mathrm{GnRH})$ antagonist (Sinha Hikim \& Swerdloff 1993, Billig et al. 1995), immunoneutralization of gonadotropin (Marathe et al. 1995, Shetty et al. 1996) or GnRH (McLachlan et al. 1995), treatment with ethane dimethanesulfonate, a cytotoxic compound for Leydig cells (Henriksen et al. 1995) or steroid implants (McLachlan et al. 1994), or use of specific animal models such as the hypogonadal mouse (O'Shaughnessy et al. 1992) or mice rendered deficient in FSH $\beta$ (Kumar et al. 1997) or FSH receptor (Dierich et al. 1998) by knockout (KO) strategies. However, it has become clear that it is difficult in vivo to perturb testosterone production independently of gonadotropin secretion and reciprocally (Sinha Hikim \& Swerdloff 1993, McLachlan et al. 1994). Moreover, obviously, the number of germ cell types at any stage of the seminiferous epithelium is dependent on the germ cell populations present at the preceding stages, a fact which may complicate, or even prevent, the interpretation of the data when some germ cell type 
numbers have become very low. Furthermore, the above studies examined the number and the state (healthy, degenerating or apoptotic) of germinal cells, but none dealt with the effect of testosterone and/or FSH on the expression of germ cell-specific genes. We have established (Weiss et al. 1997) a culture system that allows the study, in a chemically defined medium, of the expression of male germ cell-specific genes during the meiotic process. In the present study, we have used this culture system to address the specific roles of FSH and testosterone in the transformation of pachytene spermatocytes (PS) into round spermatids (RS) and in the expression of genes specific to PS or RS.

\section{Materials and methods}

\section{Isolation and coculture of rat Sertoli cells and pachytene spermatocytes (PS)}

Sertoli cells and PS were isolated as previously described (Weiss et al. 1997). Briefly, Sertoli cells were isolated from 20-day-old Sprague-Dawley rats by enzymatic digestion and plated in bicameral chambers (area $1 \mathrm{~cm}^{2}$; polyester membrane, pores $0 \cdot 4 \mu \mathrm{m}$ diameter) (Falcon, Becton-Dickinson, Meylan, France) at a density of about $3 \times 10^{5}$ cells $/ \mathrm{cm}^{2}$. Cells were then cultured for 3 days in HEPES-buffered F12/DMEM supplemented with insulin $(10 \mu \mathrm{g} / \mathrm{ml})$, transferrin $(10 \mu \mathrm{g} / \mathrm{ml})$, vitamin $\mathrm{C}\left(10^{-4} \mathrm{M}\right)$, vitamin $\mathrm{E}(10 \mu \mathrm{g} / \mathrm{ml})$, retinoic acid $\left(3.3 \times 10^{-7} \mathrm{M}\right)$, retinol $\left(3.3 \times 10^{-7} \mathrm{M}\right)$, pyruvate (1 mM) (all products from Sigma, La Verpillière, France), $0 \cdot 2 \%$ fetal calf serum (Life Technologies, Cergy-Pontoise, France) in the absence or presence of $10^{-7} \mathrm{M}$ testosterone (Sigma) and/or $1 \mathrm{ng} / \mathrm{ml}$ ovine NIH FSH-20, obtained through NIDDK and Dr A.F. Parlow (lot no. AFP-7028D).

On day 3 of culture (referred to as day 0 of coculture), PS obtained from adult SpragueDawley rats by centrifugal elutriation (Onoda et al. 1991) were seeded $\left(3 \times 10^{5}\right.$ cells $\left./ \mathrm{cm}^{2}\right)$ on Sertoli cells. The purity of the PS fraction was assessed by flow cytometry (see below) $(94 \pm 3 \%$ of the cells were $4 \mathrm{C}$ cells, $3 \pm 2 \%$ were $2 \mathrm{C}$ cells and $1 \pm 0 \cdot 5 \%$ were $1 \mathrm{C}$ cells, $n=5)$. The staging of the PS seeded was established as follows. In the first experiment, the large and the small diameters of the nuclei of the PS were measured at every stage of the seminiferous epithelium on stained histologic sections of testes from adult rats; then, the value obtained after addition of the two diameters was expressed as a percentage of the values obtained for diplotene spermatocytes (stage XIII), which is the largest type of spermatocyte. Thus, three classes of PS were defined: early PS (stages XIV-IV), the sum of the two nucleus diameters $(14 \cdot 0-15 \cdot 7 \mu \mathrm{m})$, which ranged from $59 \%$ to $66 \%$ of the value obtained for diplotene spermatocytes; middle PS (stages V-IX) $(16 \cdot 5-20.9 \mu \mathrm{m}) \quad(69-88 \%)$ and late spermatocytes (stages X-XIII) (21.6-23.8 $\mu \mathrm{m})(91-100 \%)$ (Perrard et al. 2003). In the second experiment, total germ cell preparations from adult rats were cytospun on glass slides and stained with hematoxylin/eosin. The two diameters of the spermatocytes observed (range $19 \cdot 0-32 \cdot 0 \mu \mathrm{m}$ ) were measured and expressed, as above, as a percentage of the value obtained for the largest spermatocytes found in these preparations (early PS 19.0$21.1 \mu \mathrm{m} ; \quad$ middle PS $22.0-28.2 \mu \mathrm{m} ;$ late PS $29 \cdot 0-32 \cdot 0 \mu \mathrm{m})$. In the third experiment, elutriated spermatocytes were cytospun and stained, and their diameters were measured; the values obtained were expressed as a percentage of the largest values found in total germ cell preparations (second experiment). Thus, it was found that $13 \pm 1 \%$ of elutriated PS were early PS, $61 \pm 5 \%$ were middle PS and $26 \pm 4 \%$ were late PS $(n=3)$. In some experiments, adult rats were injected with $50 \mathrm{mg} / \mathrm{kg}$ 5-bromodeoxyuridine (BrdU, Sigma) 13 or 14 days before they were killed in order to label PS of stages V-VIII or VII-XII respectively (Weiss et al. 1997). Cocultures were carried out for 2 weeks in the above medium without serum at $33^{\circ} \mathrm{C}$ in a humidified atmosphere of $95 \%$ air: $5 \% \mathrm{CO}_{2}$. The medium in the basal compartment was changed every second day. At the end of the culture period, the medium in the apical compartment was centrifuged, and the tiny cell pellet, if any, was added to the cell layer before RNA preparation, or pooled with the cells detached from the culture wells for cell sorting or identification of apoptotic cells (see below).

\section{Isolation of round spermatids (RS) and coculture with Sertoli cells}

RS from adult (90-120-day-old) Sprague-Dawley rats were isolated as previously described (Weiss et al. 1997), and then seeded $\left(3 \cdot 4 \times 10^{5} \mathrm{cells} / \mathrm{cm}^{2}\right)$ on Sertoli cells and cocultured for 4 days in the absence or presence of $10^{-7} \mathrm{M}$ testosterone 
and/or $1 \mathrm{ng} / \mathrm{ml}$ ovine FSH as above. The purity of the RS fraction was assessed by flow cytometry (see below) $(81 \pm 2 \%$ of cells were $1 \mathrm{C}$ cells, $5 \pm 1 \%$ were $2 \mathrm{C}$ cells and $10 \pm 2 \%$ were $4 \mathrm{C}$ cells, $n=3$ ).

\section{Preparation of Sertoli cell conditioned medium (SCCM)}

Rat Sertoli cells were plated in tissue-culture flasks at a density of $0.2 \times 10^{6}$ cells $/ \mathrm{cm}^{2}$ and were cultured for 3 days in the above medium supplemented with $0.2 \%$ fetal calf serum in the absence or presence of $\mathrm{FSH}$ and/or testosterone or $10^{-9} \mathrm{M}$ ACTH. On day 3 , the medium was replaced by serum-free medium supplemented or not with hormones. On day 5 , culture medium was recovered, centrifuged to eliminate cell debris and stored at $-20{ }^{\circ} \mathrm{C}$ until used. Four SCGM were prepared: control (no $\mathrm{FSH}$, no testosterone (F-/T-)), FSH (1 ng/ml) $(\mathrm{F}+/ \mathrm{T}-)$, testosterone $10^{-7} \mathrm{M}(\mathrm{F}-/ \mathrm{T}+)$ and a combination of both hormones $(\mathrm{F}+/ \mathrm{T}+)$.

\section{Preparation of conditioned media from adrenocortical cells}

Rat adrenocortical cells were isolated by the procedure described previously for bovine adrenocortical cells (Penhoat et al. 1994) and plated in tissue-culture flasks at a density of $0.2 \times 10^{6}$ cells $/ \mathrm{cm}^{2}$ in Hepes-buffered F12/DMEM supplemented as for Sertoli cells (see above) and containing $1 \%$ fetal calf serum. On the day after, the medium was replaced by serum-free medium supplemented or not with $10^{-9} \mathrm{M} \mathrm{ACTH}$ or FSH plus testosterone. On day 3, the culture medium was recovered, centrifuged and conserved at $-20{ }^{\circ} \mathrm{C}$ until used. Adrenocortical cells were chosen as they could be cultured in the same medium as Sertoli cells.

\section{Incubation of RS in conditioned medium}

RS isolated from 32-day-old Sprague-Dawley rats by centrifugal elutriation were incubated $\left(1.0 \times 10^{6}\right.$ cells $/ 1.5 \mathrm{ml}$ ) for $24 \mathrm{~h}$ in the different conditioned medium half-diluted with fresh culture medium. Of cells present in RS preparations, $55 \pm 2 \% \quad(n=7)$ were $1 \mathrm{C}$ cells, $27 \pm 1 \%$ were $2 \mathrm{C}$ cells and $8 \pm 2 \%$ were $4 \mathrm{C}$ cells. In these experiments, 32-day-old animals were used, since, at that age, TP1 expression is not yet maximal (Marret et al. 1998).

\section{RNA preparation and analysis}

At selected days of the cocultures, or after incubation of RS, total RNA was extracted by the method of Chomczynski and Sacchi (1987).

\section{Reverse transcription-polymerase chain reaction (RT- PCR)}

RNA extracted from cocultures of Sertoli cells-PS was analyzed by RT-PCR. Sequences corresponding to TPl mRNAs and TH2B mRNAs were amplified by RT-PCR in the presence of $[\alpha-33 \mathrm{P}]$ dATP (ICN, Orsay, France), as previously described (Weiss et al. 1997, Hue et al. 1998).

\section{Northern blot}

The amounts of TP1 mRNAs in RS fractions were determined by Northern blot. Samples $(6 \mu \mathrm{g}$ of total RNA) were separated by electrophoresis through a $1 \%$ agarose gel containing $10 \%$ formaldehyde. RNA was then transferred to a Hybond-N membrane (Amersham, Les Ulis, France) and cross-linked to the membrane by baking at $80{ }^{\circ} \mathrm{C}$ for $2 \mathrm{~h}$ and by irradiation for $13 \mathrm{~s}$ with u.v. light. Prehybridization and hybridization were performed at $42{ }^{\circ} \mathrm{C}$ for $2 \mathrm{~h}$ and overnight respectively. The rat cDNA probe for TP1 (175 bp) was obtained after amplifying the TP1 sequence by RT-PCR. Labeling of this probe with $[\alpha-32 \mathrm{P}]$ dCTP (Amersham) was performed with a Megaprime DNA labeling system (Amersham). The labeled probe was added to hybridization solutions at a concentration of $1 \times$ $10^{6} \mathrm{~d} . \mathrm{p} . \mathrm{m} . / \mathrm{ml}$. The blots were then washed twice in $2 \times \mathrm{SSG}(1 \times \mathrm{SSG}=150 \mathrm{mM} \mathrm{NaCl}$ and $15 \mathrm{mM}$ sodium citrate, $\mathrm{pH} 7 \cdot 4$ ), SDS $0 \cdot 1 \%$ for $15 \mathrm{~min}$ at room temperature; twice in $1 \times \mathrm{SSC}$, SDS $0 \cdot 1 \%$ for $15 \mathrm{~min}$ at $65^{\circ} \mathrm{C}$; twice in $0.5 \times \mathrm{SSC}$, SDS $0 \cdot 1 \%$ for $15 \mathrm{~min}$ at $65^{\circ} \mathrm{C}$ and twice in $0.2 \times \mathrm{SSG}$, SDS $0 \cdot 1 \%$ for $15 \mathrm{~min}$ at $65^{\circ} \mathrm{C}$, and then exposed to photographic film. The relative intensities of hybridization signals were quantified with a scanning densitometer (SAMBA 2005; Alcatel TITN, Meylan, France). Portions of membrane corresponding to 28S rRNA were hybridized with a radiolabeled 28S oligonucleotide probe (Barbu \& Dautry 1989). All values for TP1 mRNAs levels were normalized relative to levels of $28 \mathrm{~S}$ to correct for potential differences in the amounts of loaded RNA. 


\section{Identification of apoptotic cells by annexin V-binding assay}

Cells were isolated at selected days of culture by IX trypsin-EDTA (Life Technologies) for 3-5 min. Then, soybean trypsin inhibitor (Sigma) was added to stop trypsin action, and the cells were placed in a humidified atmosphere of $95 \%$ air: $5 \% \mathrm{CO}_{2}$ for $1 \mathrm{~h}$ at $33{ }^{\circ} \mathrm{C}$. The cells were then centrifuged, and cell pellets were washed twice. The analysis of phosphatidylserine on the outer leaflet of apoptotic cell membrane was performed with annexin-Vfluos (Roche Diagnostics, Meylan, France) and propidium iodide (Sigma) to differentiate necrotic cells from apoptotic cells, according the instructions of the manufacturer. Then, cells were fixed in $4 \%$ paraformaldehyde for $10 \mathrm{~min}$, at $4{ }^{\circ} \mathrm{C}$ and washed twice in $1 \times$ PBS.

\section{Immunocytochemical reaction against vimentin}

To distinguish between somatic cells and germ cells, an immunocytochemical reaction against vimentin (solely expressed by somatic cells in the testis) was performed as follows. The cells were deposed on 3-aminopropyltriethoxysilane pretreated slides and permeabilized with Triton X-100 $0.03 \%$ in PBS. The cells were then incubated with $3 \%$ hydroxide peroxide (Gifrer and Barbezat, Décines, France) for $5 \mathrm{~min}$ in a humidified dark chamber at room temperature, rinsed with PBS, and then incubated for $10 \mathrm{~min}$ with a mouse monoclonal antibody (clone v9), which recognizes vimentin filaments (at 1:1000 dilution in antibody diluent). After washing in PBS, the cells were incubated with a second biotinylated antibody (Multilink-biotin anti-goat, mouse and rabbit antibody) for $10 \mathrm{~min}$ (at 1:150 dilution in antibody diluent). Then, the cells were washed for $10 \mathrm{~min}$ in PBS. The staining reaction was performed with streptavidin-biotinylated horseradish peroxidase (StrepABC Complex/HRP) and diaminobenzidine as a chromogen (all products from Dako, Trappes, France).

\section{Quantification of apoptotic germ cells}

Slides were examined under light and fluorescence microscopy with an Axioscope microscope (Carl Zeiss, Oberkochen, Germany). Two measures were performed: first, germ cells were identified (at least 500 cells were counted, in duplicate samples) by light microscopy (germ cells were vimentin negative); second, the number of apoptotic germ cells was determined by fluorescence microscopy. Necrosis represented 3-5\% of positive annexin-Vfluos cells, and no variations were observed during cocultures. The validity of this method was assessed by treating cocultures with different concentrations of $\mathrm{H}_{2} \mathrm{O}_{2}$, which induced a dose-dependent increase in the number of apoptotic germinal cells (data not shown).

\section{Identification of apoptotic cells by TUNEL assay}

Cells were isolated at selected days of culture by trypsin-EDTA as above and fixed in cold ethanol $70 \%$. Cells were permeabilized with $0 \cdot 25 \%$ Triton $\mathrm{X} 100$ in PBS for $20 \mathrm{~min}$ on ice. The cells were exposed to an antivimentin antibody (see above) at 1:500 dilution. After three washes in PBS, the cells were exposed to fluorescein (FITG)conjugated rabbit antimouse immunoglobulins (Ig) (IgG, Dako) used at a dilution of 1:60 in PBS for $1 \mathrm{~h}$ at $4{ }^{\circ} \mathrm{C}$. TUNEL assay was performed with the In Situ Gell Death Detection Kit, TMR Red (Roche Diagnostics), according to the instructions of the manufacturer. Before analysis, Hoechst 33342 (Sigma) was added to the suspensions of labeled cells at a final concentration of $20 \mu \mathrm{g} / \mathrm{ml}$. Two controls were included: 1. cells incubated with mouse IgGl negative control (Dako) and FITC-conjugated secondary antibody; 2 . cells incubated with label solution without terminal transferase. Cells were then analyzed by flow cytometry (see below).

\section{Flow cytometry}

Flow cytometry analysis of both germ cells and somatic cells was performed as described by Godet et al. $(2000,2004)$.

\section{Immunocytochemical studies on cultured cells}

Cells were rinsed with PBS and fixed with Bouin's fixative at room temperature. After 5 washes with PBS, immunocytochemical reactions against a 90-kDa protein specific to the acrosome (Tanii et al. 1994) or BrdU were performed as previously described in detail (Weiss et al. 1997). The morphologic identification of the different types of 
Table 1 Percentage of apoptotic germinal cells in cocultures of PS and Sertoli cells under different hormonal conditions

a) Annexin $V$ binding assay

\begin{tabular}{|c|c|c|c|c|}
\hline & \multicolumn{4}{|l|}{ Treatments } \\
\hline & FSH-/Testo-(a) & $\mathrm{FSH}+/$ Testo-(a,b) & $\mathrm{FSH}-/$ Testo+ ${ }^{(\mathrm{a}, \mathrm{b})}$ & $\mathrm{FSH}+/$ Testo $+{ }^{(\mathrm{b})}$ \\
\hline \multicolumn{5}{|l|}{ Days of coculture } \\
\hline 2 & $11 \pm 2^{a}$ & $10 \pm 3^{a}$ & $11 \pm 3^{a}$ & $8 \pm 1^{a}$ \\
\hline 5 & $15 \pm 4^{a}$ & $13 \pm 1^{a}$ & $13 \pm 3^{a}$ & $12 \pm 3^{a}$ \\
\hline 8 & $21 \pm 2^{a}$ & $18 \pm 2^{a b}$ & $18 \pm 3^{a b}$ & $15 \pm 1^{b}$ \\
\hline 11 & $26 \pm 2^{a}$ & $22 \pm 4^{a}$ & $23 \pm 5^{a}$ & $17 \pm 3^{b}$ \\
\hline 15 & $24 \pm 1^{a}$ & $26 \pm 2^{a}$ & $23 \pm 2^{a b}$ & $22 \pm 1^{b}$ \\
\hline
\end{tabular}

b) TUNEL assay

\begin{tabular}{|c|c|c|c|c|}
\hline & \multicolumn{4}{|l|}{ Treatments } \\
\hline & $\overline{\mathrm{FSH}-/ T e s t o-(\mathrm{a})}$ & FSH+/Testo-(a) & FSH-/Testo+(a) & $\mathrm{FSH}+/$ Testo $+(\mathrm{a})$ \\
\hline \multicolumn{5}{|l|}{ Days of coculture } \\
\hline 2 & $3 \cdot 8 \pm 0 \cdot 8^{a}$ & $3.5 \pm 1 \cdot 0^{\mathrm{a}}$ & $3 \cdot 6 \pm 0 \cdot 8^{a}$ & $2 \cdot 8 \pm 0 \cdot 4^{a}$ \\
\hline 5 & $4 \cdot 6 \pm 1 \cdot 7^{a}$ & $4 \cdot 4 \pm 1 \cdot 4^{a}$ & $3.3 \pm 0.7^{a}$ & $3.7 \pm 0.9^{a}$ \\
\hline 8 & $4 \cdot 7 \pm 0 \cdot 6^{a}$ & $4 \cdot 6 \pm 1 \cdot 4^{a}$ & $4 \cdot 4 \pm 1 \cdot 0^{\mathrm{a}}$ & $4 \cdot 8 \pm 1 \cdot 0^{a}$ \\
\hline 11 & $6 \cdot 0 \pm 2 \cdot 6^{a}$ & $5 \cdot 4 \pm 1.4^{a}$ & $6 \cdot 2 \pm 2 \cdot 3^{a}$ & $5 \cdot 1 \pm 1.9^{a}$ \\
\hline 15 & $8.5 \pm 3.7 a$ & $7 \cdot 6 \pm 2 \cdot 3^{a}$ & $8 \cdot 5 \pm 5 \cdot 2^{a}$ & $8 \cdot 6 \pm 2 \cdot 1^{a}$ \\
\hline
\end{tabular}

PS were cultured in the absence (FSH-/Testo-) or presence of FSH (FSH+/Testo-) or testosterone (FSH-/Testo+) or both (FSH+/Testo+). The percentage of apoptotic germ cells was determined at selected days of culture as described in the Materials and methods section. Each value is the mean \pm S.E.M. of three different experiments. Treatments with different superscripts are significantly different $(P<0.05)$; moreover, within lines, values with different superscripts are significantly different.

germ cells was performed according to the criteria described by Russell et al. (1990).

\section{Statistical analysis}

Two-way analysis of variance followed by the Bonferroni/Dunn a posteriori tests or paired Student's $t$-test was used. When required, values were logarithmically transformed to eliminate heterogeneity of variance. Differences were considered significant at $P<0 \cdot 05$.

\section{Results}

\section{Effects of FSH and/or testosterone on apoptosis of germ cells}

When PS were cocultured with Sertoli cells, the total number of cells (somatic cells plus germ cells) decreased during the 2 weeks of the experiment in such a way that on day 15 , the percentage of cells, compared with day 1 , was $69 \pm 6 \%$ (mean \pm S.E.M. for six different experiments) irrespective of the absence or presence of either FSH or testosterone in the culture medium. Likewise, neither hormone influenced the viability of the cocultures, which decreased slightly between days $1(87 \pm 2 \%)$ and 15 $(72 \pm 1 \%)$. This latter result was completed by determining the percentage of apoptotic cells in the cultures by two methods. As shown in Table la and $b$, the proportion of apoptotic germinal cells increased steadily during culture by about threefold by either method $(P<0 \cdot 05)$. Treatment with both FSH and testosterone reduced slightly the percentage of apoptotic germinal cells in the cultures when compared with cells cultured in the absence of hormones $(P<0 \cdot 05)$ only when assessed by annexin $\mathrm{V}$ binding. The percentages of apoptotic germinal cells in cultures treated with either FSH or testosterone were different neither from control cultures nor from cultures treated with both hormones. When germ cells were analyzed according to their ploidy, the proportion of apoptotic cells, determined by TUNEL assay, 
increased roughly twofold, during the culture period, in the $1 \mathrm{C}$ - and $2 \mathrm{C}$-cell populations, whereas it increased threefold in the 4C-cell population (all $P<0 \cdot 05)$. However, neither hormone treatment modified significantly the percentage of apoptotic cells in either population (data not shown). The proportion of somatic apoptotic cells was always low (less than 2\%; data not shown).

\section{Effects of FSH and/or testosterone on the number of in vitro differentiated RS}

The number of somatic cells remained roughly constant during the first 4 days of culture, and then it increased $1 \cdot 7$-fold under either culture condition (Fig. 1a). The number of PS cocultured with Sertoli cells decreased during the 2-week culture period, irrespective of the absence or presence of hormone in the culture medium (Fig. 1b). Some of the PS differentiated into RS, as illustrated on Fig. 2, which presents cytologic evidence that PS (either labeled or unlabeled with BrdU) completed the two meiotic divisions throughout the culture period. When FSH was present in the culture medium, either alone or together with testosterone, the number of in vitro formed RS was higher than that in control wells (range $1 \cdot 8-5 \cdot 4$-fold between days 3 and 8 of culture) (Fig. 1c). Likewise, when testosterone alone was added to the culture medium, the number of RS was 1.2-2-fold higher than in controls on those days (Fig. 1c). Such an effect of FSH and/or testosterone was observed in six different experiments, as shown in Table 2a, which reports the percentages of $1 \mathrm{C}-, 2 \mathrm{C}$ - or 4C-germ cell populations in short-term cocultures of PS and Sertoli cells performed under different hormonal conditions. The proportion of $4 \mathrm{C}$ cells was slightly but significantly $(P<0.05)$ higher in the absence of hormone than under all other conditions, whereas no difference among the different treatments was observed for the $2 \mathrm{C}$ cell populations. By contrast, the percentage of $1 \mathrm{C}$ cells was higher than that of controls, when FSH and/or testosterone were/was present in the culture medium. This resulted in higher meiotic indexes in hormonetreated cocultures than in controls (Table 2b). Taken together, these results suggest that both the first and second meiotic divisions are positively influenced by the presence of FSH or testosterone.

The $2 \mathrm{C}$ germ cell population is composed of a mix of secondary spermatocytes and of doublets of

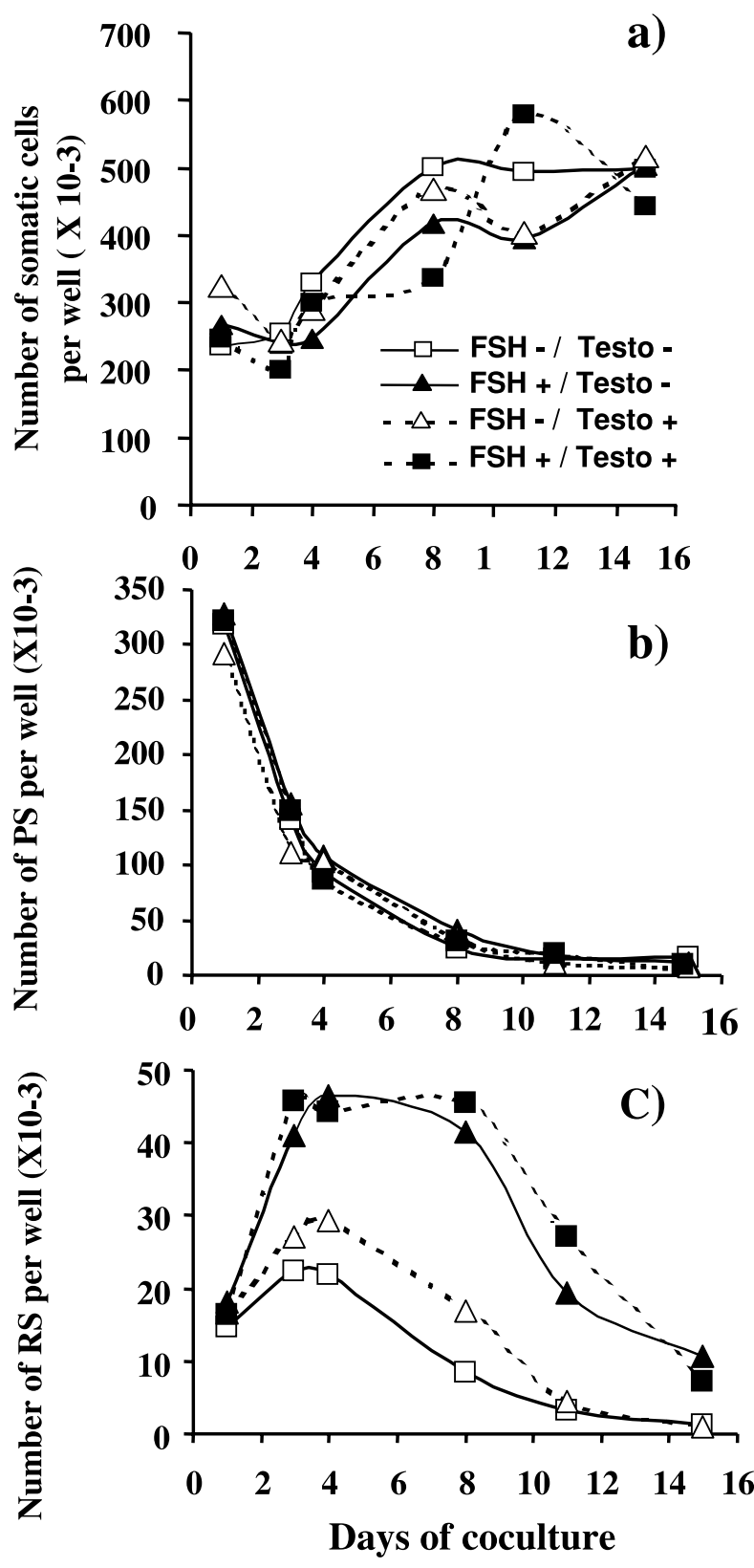

Figure 1 Changes in the number of somatic cells (a) pachytene spermatocytes (PS) (b) and of round spermatids (RS) (c) in a representative coculture of PS and Sertoli cells under different hormonal conditions (FSH-/Testo- control; FSH+/Testo- in presence of $\mathrm{FSH}$ alone; $\mathrm{FSH}$-/Testo+ in presence of testosterone alone; $\mathrm{FSH}+$ /Testo+ in presence of both hormones).

RS (Godet et al. 2000), and the number of secondary spermatocytes results from an equilibrium between the two meiotic divisions. Hence, small differences in the number of secondary 

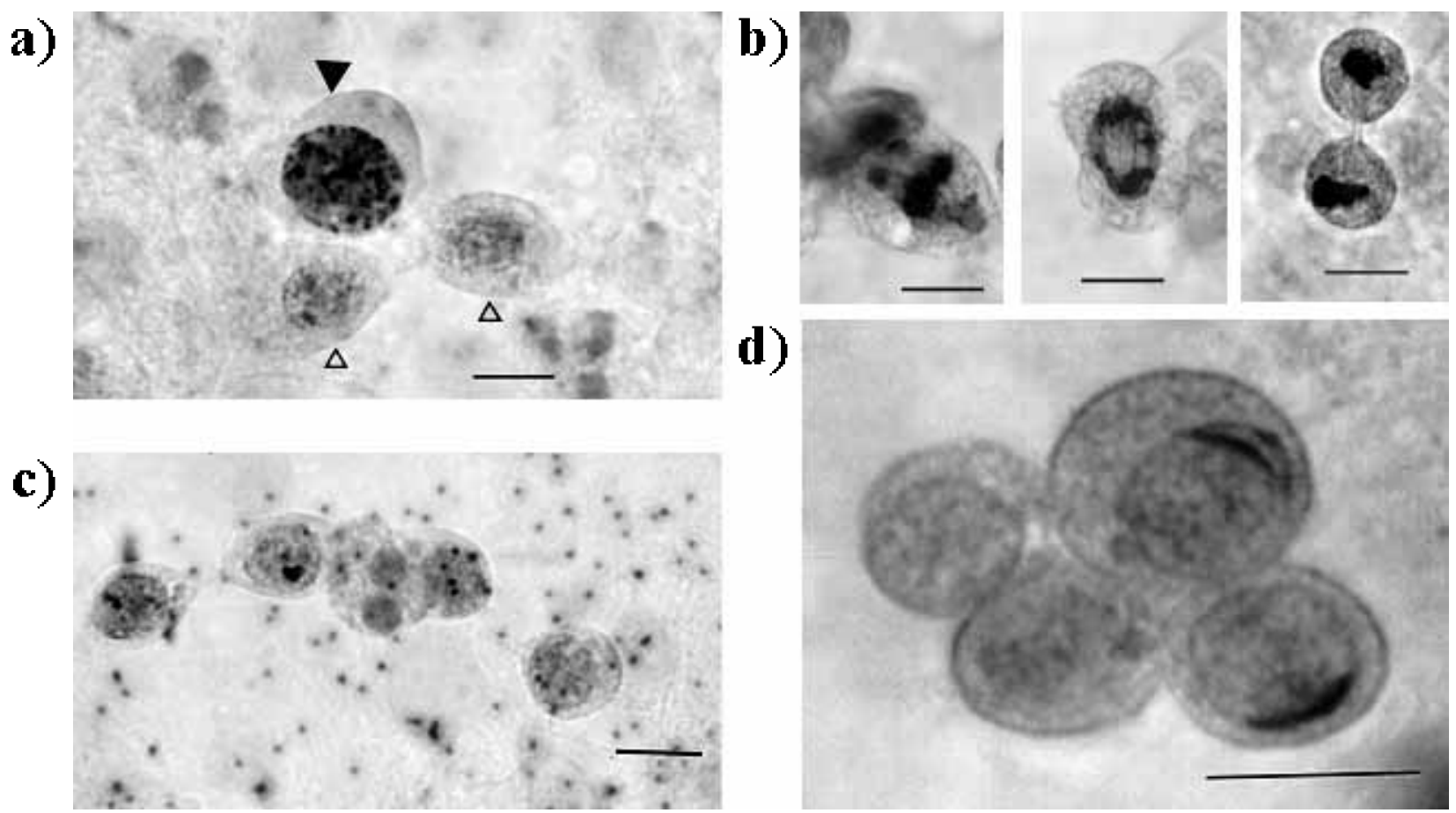

Figure 2 Cytologic and immunocytochemical analysis of the differentiation of PS cultured on Sertoli cells. (a) One large BrdU-labeled PS $(\boldsymbol{\nabla})$ and two BrdU-labeled secondary spermatocytes $(\Delta)$ on day 5 of culture. (b) Meiotic metaphasis (left), anaphasis (middle) and telophasis (right) of BrdU-labeled spermatocytes on day 5 of culture. (c) Four BrdU-labeled RS on day 9 of culture. (d) Immunocytochemical staining of the acrosomal granules of RS (stages 5-6) on day 11 of culture. All bars represent $10 \mu \mathrm{m}$.

spermatocytes may not be detected by analysis of total cells. Therefore, in additional experiments, BrdU-labeled PS of stages VII-XII were cocultured with Sertoli cells in the absence or presence of hormones; then, the number of BrdU-labeled primary and secondary spermatocytes and that of BrdU-labeled RS were assessed by microscopic examination of the culture wells on day 3 of culture. The data presented in Table 3 show that, indeed, in the presence of both hormones, the number of secondary spermatocytes and of RS was significantly higher than in control cultures.

\section{Effects of FSH and/or testosterone on the survival of RS cultured with Sertoli cells}

The higher number of RS in hormone-treated cultures could be due to an enhancement of the completion of meiosis of seeded PS but also to improved survival of RS. Therefore, in the next experiments, purified RS were cocultured with Sertoli cells for 4 days, in either the absence or presence of FSH and/or testosterone, and the number of RS was determined every day. As expected (Weiss et al. 1997), there was a steady decrease in the haploid population (data not shown) during the culture period. More important, neither hormone, either alone or in combination, influenced the half-life of RS under the present culture conditions (Table 4).

\section{Effects of FSH and/or testosterone on the amounts of mRNAs specific for PS or RS in cocultures of PS and Sertoli cells}

Next, we studied the changes in the levels of mRNAs encoding for the testis-specific histone TH2B (specific to PS) and the mRNAs encoding for the transition protein TP1 (specific to RS) (Marret et al. 1998) in cells cultured under different hormonal conditions. The amount of radioactivity incorporated in each PGR product within the exponential phase of the reaction, at every day of culture studied, was expressed as a percentage of the radioactivity incorporated in the corresponding product on day 0 of the experiment (Weiss et al. 1997, Hue et al. 1998) (Fig. 3). The steady decrease 
Table 2 In vitro effects of FSH and/or testosterone on a) the proportions of germ cells of different ploidy; b) the calculated meiotic index

a) Percentage of total germ cells

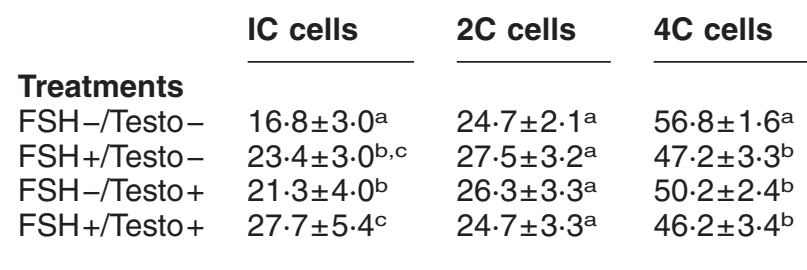

\section{b) Calculated meiotic index}

$\begin{array}{ll}\text { Treatments } & \\ \text { FSH-/Testo- } & 0.78 \pm 0.25^{\mathrm{a}} \\ \text { FSH+/Testo- } & 1.27 \pm 0.28^{\mathrm{c}} \\ \text { FSH-/Testo+ } & 0 \cdot 99 \pm 0.28^{\mathrm{b}} \\ \text { FSH+/Testo+ } & 1.27 \pm 0.35^{\mathrm{c}}\end{array}$

PS were cocultured with Sertoli cells for $3-5$ days in the absence (FSH-/Testo-) or presence of FSH (FSH+/Testo-) or testosterone (FSH-/Testo+) or both (FSH+/Testo+). DNA flow cytometry analysis of germ cells was performed as described in the Materials and methods section. Values are the mean \pm S.E.M. of six different experiments. Within columns, values with different superscripts are significantly different $(P<0.05)$.

The meiotic index was calculated by dividing the number of RS formed in vitro by the number of late PS seeded $(26 \pm 4 \%$ of total PS seeded: see Materials and methods section).

$(P<0.05)$ of the amount of TH2B mRNAs throughout the culture was similar to that observed in a previous work (Weiss et al. 1997), and neither hormone influenced significantly the variations of these levels (Fig. 3a). By contrast, the amount of
Table 4 Half-lives of round spermatids cocultured with Sertoli cells under different hormonal conditions

$$
\text { Half-life (days) }
$$

Hormonal treatment
FSH-/Testo-
FSH+/Testo-
FSH-/Testo+
FSH+/Testo+

$1 \cdot 6 \pm 0 \cdot 4$

$1 \cdot 7 \pm 0 \cdot 3$

$1 \cdot 5 \pm 0 \cdot 3$

$1 \cdot 6 \pm 0 \cdot 2$

RS were cocultured with Sertoli cells for 4 days in the absence or presence of $\mathrm{FSH}$ and/or testosterone. The number of remaining RS was determined by flow cytometry on every day, allowing the determination of their half-life in culture. Each value is the mean \pm S.E.M. of four different experiments. No significant difference between the values was observed.

TP1 mRNAs increased four- to fivefold when both $\mathrm{FSH}$ and testosterone were present in the culture medium $(P<0 \cdot 05$ on days 8,11 and 15 vs day 0$)$ (Fig. 3b). Moreover, the amount of TPl mRNAs on day 15 was higher $(P<.0 \cdot 05)$ than that of control cells when FSH was present in the culture medium either alone or in the presence of testosterone. When testosterone alone was present, the amount of TP1 mRNAs on day 15 was similar to that observed in the presence of FSH alone, but the higher variability of the value made the difference with controls not significant.

\section{Effects of different SCCM on TP1-mRNA contents of RS}

The enhanced amounts of the mRNAs encoding for TP1 in hormone-treated cocultures of PS and

Table 3 Numbers of BrdU-labeled PS, of BrdU-labeled secondary spermatocytes and BrdU-labeled RS on day 3 of cocultures of BrdU-labeled PS of stages VII-XII and Sertoli cells under different hormonal conditions

\begin{tabular}{|c|c|c|c|}
\hline & $\begin{array}{l}\text { Number of } \\
\text { PS/mm }\end{array}$ & $\begin{array}{l}\text { Number of secondary } \\
\text { spermatocytes/mm }\end{array}$ & $\begin{array}{l}\text { Number of } \\
\text { RS/mm }\end{array}$ \\
\hline $\begin{array}{l}\text { Treatments } \\
\text { FSH-/Testo- } \\
\text { FSH+/Testo- } \\
\text { FSH-/Testo+ } \\
\text { FSH+/Testo+ }\end{array}$ & $\begin{array}{l}27 \cdot 3 \pm 4 \cdot 4^{a} \\
24 \cdot 5 \pm 5 \cdot 2^{a} \\
30 \cdot 8 \pm 5 \cdot 7^{a} \\
27 \cdot 0 \pm 5 \cdot 0^{a}\end{array}$ & $\begin{array}{l}1 \cdot 5 \pm 0 \cdot 4^{\mathrm{a}} \\
2 \cdot 0 \pm 0 \cdot 8^{\mathrm{ab}} \\
2 \cdot 4 \pm 0 \cdot 8^{\mathrm{b}} \\
2 \cdot 5 \pm 0 \cdot 3^{\mathrm{b}}\end{array}$ & $\begin{array}{l}1 \cdot 4 \pm 0 \cdot 4^{a} \\
2 \cdot 1 \pm 0 \cdot 8^{a b} \\
2 \cdot 0 \pm 0 \cdot 8^{a b} \\
3 \cdot 0 \pm 0 \cdot 8^{b}\end{array}$ \\
\hline \multicolumn{4}{|c|}{$\begin{array}{l}\text { BrdU-labeled PS of stages VII-XII were cocultured with Sertoli cells for } 3 \text { days in the absence } \\
\text { (FSH-/Testo-) or presence of FSH (FSH+/Testo-) or testosterone (FSH-/Testo+) or both } \\
\text { (FSH+/Testo+). On day 3, the number of BrdU-labeled PS and secondary spermatocytes and of } \\
\text { BrdU-labeled RS was determined by microscopic examination of the culture wells and expressed as th } \\
\text { number of each cell type per } \mathrm{mm} \text { of well and on the width of the microscope field objective } \times 100) \text {. At } \\
\text { least } 500 \text { BrdU-labeled spermatocytes and/or RS were counted in each condition. } \\
\text { Values with different superscripts are significantly different }(P<0.05) \text {. }\end{array}$} \\
\hline
\end{tabular}



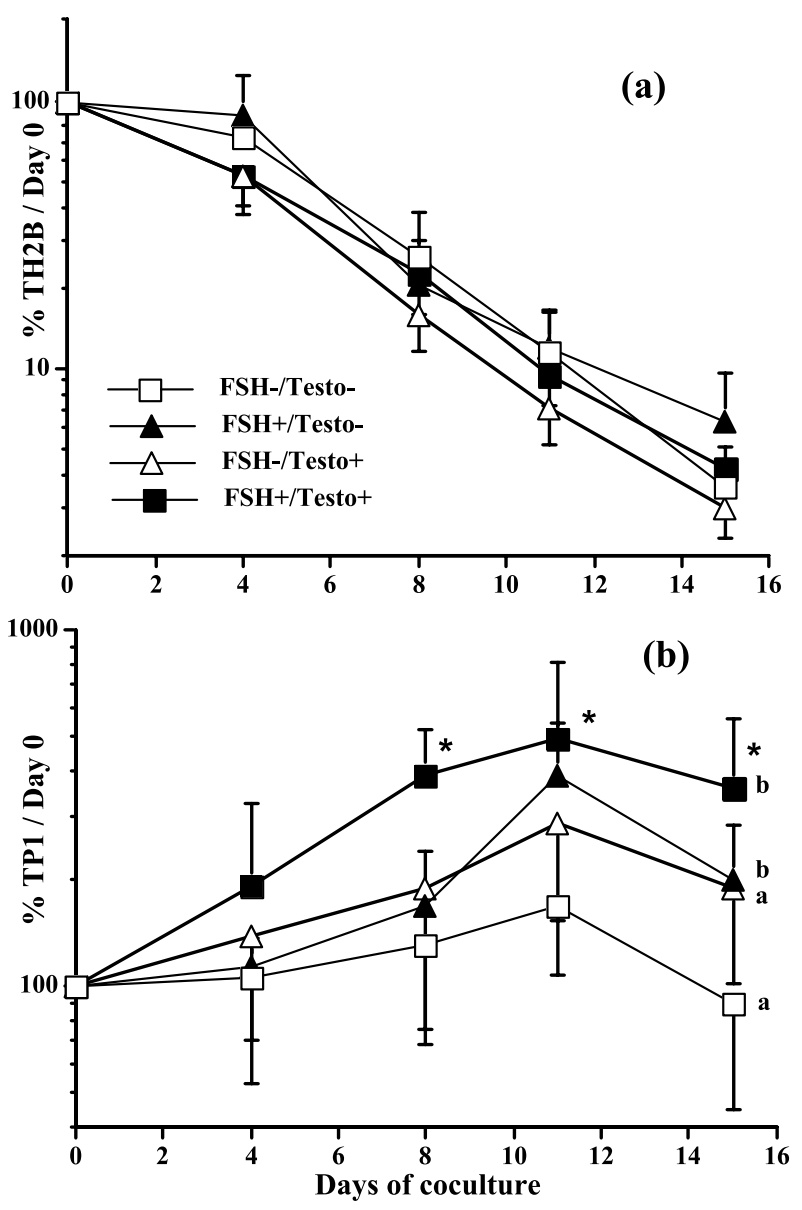

Figure 3 Changes in the amount of radioactivity incorporated in TH2B (a) or in TP1 (b) mRNA-related PCR products in cocultures of PS and Sertoli cells under different hormonal conditions. The results are the mean \pm S.E.M. from triplicate cultures in three different experiments and are expressed as a percentage of the radioactivity incorporated in these respective $P C R$ products on day 0 of coculture. The number of c.p.m. at 19-20 cycles of PCR amplification corresponding to $100 \%$ was $39000 \pm 6700$ for TH2B and $14600 \pm 2100$ for TP1. Note the logarithmic scale of the y-axis. On day 15 , values with different superscripts are significantly different $(P<0.05)$. Values labeled with asterisks are significantly different from day $0(P<0.05)$.

Sertoli cells could be due to the higher proportion of RS formed in these cultures, and/or to an enhancement in the transcription of this gene by the hormones. In an attempt to clarify this point, in another series of experiments, RS prepared by elutriation from 32-day-old rat testes were incubated for $24 \mathrm{~h}$ in serum-free conditioned media from Sertoli cells cultured in the absence or presence of FSH and/or testosterone (see Materials and methods section). Then, the amounts of TP1 mRNAs were measured. The viability of RS decreased during the 24-h incubation period from $97 \pm 1 \%$ to $80 \pm 2 \%$, irrespective of the presence or absence of hormones in the conditioned media. When RS were incubated with medium from Sertoli cells cultured without hormone, their contents in TP1 mRNAs tended to be lower than those of freshly isolated RS (Fig. 4). By contrast, when RS were incubated in medium from Sertoli cells cultured in the presence of either FSH or testosterone, their TP1 mRNA contents were not different from those of freshly isolated RS, but were two- to threefold higher than those of RS maintained in medium from Sertoli cells cultured without hormone (all $P<0 \cdot 05$ ). As for RS incubated in medium from Sertoli cells cultured in the presence of both FSH and testosterone, their content in TP1 mRNAs was even higher than that of freshly isolated RS. These effects appear to be specific to SCGM, since they were not observed when media were conditioned by adrenocortical cells (Table 5).

\section{Discussion}

The cytologic monitoring of the fate of PS seeded on Sertoli cell layers clearly demonstrates that some of them can go through the two meiotic divisions under the present culture conditions. Besides, several teams have now demonstrated that meiosis can proceed in vitro when mammalian spermatogenic cells are cocultured with Sertoli cells (Parvinen et al. 1983, Weiss et al. 1997, Hue et al. 1998, Staub et al. 2000, Lee et al. 2001, Sousa et al. 2002, Godet et al. 2004). In rodents, the kinetics of the meiotic process is similar in vivo and during the first week of culture (Parvinen et al. 1983, Perrard et al. 2003), but the efficiency of the meiosis events is somewhat lower than in vivo; this can be explained partly by a higher proportion of apoptotic $1 \mathrm{C}$ cells in culture and a bottleneck at the transition from middle to late PS which would lead to the phagocytosis of PS by the Sertoli cells (Perrard et al. 2003). Nevertheless, it has been shown recently that RS developed in vitro can produce normal offspring in the mouse (Marh et al. 2003). Taken together, these results support the use of such culture systems to address some aspects of the meiotic process (Weiss et al. 1997, Godet et al. 2004). 

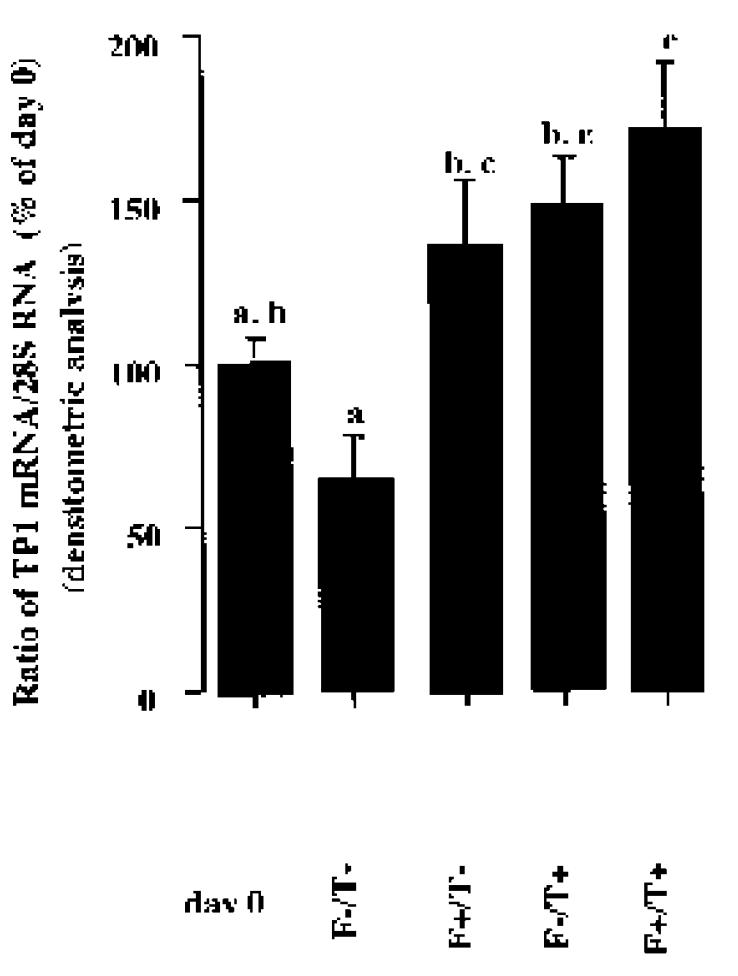

286

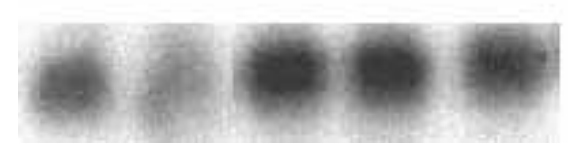

TP1

Figure 4 Effects of different Sertoli cell conditioned media (SCCM) on the TP1 mRNA/28S RNA ratio of RS. Top: elutriated RS were incubated for $24 \mathrm{~h}$ in serum-free conditioned medium from Sertoli cells cultured in the absence ( $\mathrm{F}-/ \mathrm{T}-)$ or presence of $\mathrm{FSH}(\mathrm{F}+/ \mathrm{T}-)$ or testosterone $(\mathrm{F}-/ \mathrm{T}+)$ or both $(\mathrm{F}+/ \mathrm{T}+)$; RNA was analyzed by Northern blotting (day 0: freshly elutriated RS). Each point is the mean \pm S.E.M. from six experiments. Values with different superscripts are significantly different $(P<0.05)$. Bottom: representative Northern blot of TP1 transcripts of freshly isolated (day 0 ) RS or of RS incubated in different SCCM for $24 \mathrm{~h}$.

We have shown in the present study that, in vitro, both FSH and testosterone influence positively the completion of the meiotic process of spermatogenic cells, as well as the levels of TP1 mRNAs specifically expressed in RS. The concentration of FSH we used was shown, in preliminary experiments, to stimulate maximally the changes in the

p19/TP1 and TH2B/TP2 ratios which occur when PS are cocultured with Sertoli cells for a 2-week period (Weiss et al. 1997, and unpublished results). Furthermore, this concentration of FSH is close to that used by Henriksen et al. (1996) ( $2 \mathrm{ng} / \mathrm{ml}$ of $\mathrm{FSH}$ from another source), giving a near maximal effect in experiments of incubation of seminiferous tubular segments. As for testosterone, a 'physiologic' concentration (Maddocks \& Sharpe 1989) was chosen.

Neither the total (germinal and somatic) number of cells nor their viability was significantly altered by either hormonal treatment, whereas FSH in combination with testosterone decreased slightly the proportion of apoptotic germinal cells as determined by annexin V-binding assay. This former result is indeed explained by the fact that very few, if any, apoptotic somatic cells have ever been observed under the present culture conditions. Therefore, the 'dilution' of germinal cells with somatic cells made the small differences observed in total cell viability nonsignificant. Two different methods were used to detect apoptotic cells in the present study. The appearance of phosphatidyl serine on the outer leaflet of cell membrane detected by annexin $\mathrm{V}$ binding is an early event in the apoptotic process, while DNA fragmentation (TUNEL assay) is a latter event. The proportions of apoptotic germ cells, determined in the present study, by these two methods were rather low, at least during the first week of culture. This appears to contradict the somewhat large decrease in PS during the early culture period. No definite explanation can be given at the present time, but it might be that the number of degenerating cells was underestimated due to the rapid phagocytosis of apoptotic cells, as has been shown in other tissues (Raff et al. 1993). This assumption seems rather likely, as Sertoli cells are highly phagocytic (Byers et al. 1993). This property of Sertoli cells might also explain, at least partly, the lower percentages of apoptotic germinal cells measured by TUNEL assay than by annexin $\mathrm{V}$ binding. These results fit quite well with the proportions of apoptotic germ cells determined by measuring the level of activated caspase 3 in freshly isolated germ cell preparations or in cultured seminiferous tubules (Perrard et al. 2003). Many in vivo studies have shown that both FSH and testosterone decrease apoptosis of both PS and RS of the rat (Billig et al. 1995, Brinckworth et al. 1995, 
Table 5 Effects of media conditioned by different types of cells on the contents in TP1 mRNA of round spermatids

\begin{tabular}{|c|c|c|}
\hline & $\begin{array}{l}\text { Sertoli cell conditioned } \\
\text { medium }\end{array}$ & $\begin{array}{l}\text { Adrenocortical cell } \\
\text { conditioned medium }\end{array}$ \\
\hline $\begin{array}{l}\text { ontrol } \\
\text { SH }(1 \mathrm{ng} / \mathrm{ml})\end{array}$ & $100 \pm 16$ & $108 \pm 12$ \\
\hline $\begin{array}{l}\text { +testosterone }\left(10^{-7} \mathrm{M}\right) \\
\mathrm{ACTH}\left(10^{-9} \mathrm{M}\right)\end{array}$ & $\begin{array}{c}225 \pm 40^{*} \\
97 \pm 3\end{array}$ & $\begin{array}{c}97 \pm 9 \\
100 \pm 19\end{array}$ \\
\hline \multicolumn{3}{|c|}{$\begin{array}{l}\text { Sertoli cells or adrenocortical cells were cultured in the absence or presence of FSH+ } \\
\text { testosterone or ACTH, and conditioned media were prepared as described in the } \\
\text { Materials and methods section. Elutriated round spermatids were incubated for } 24 \mathrm{~h} \text { in } \\
\text { these conditioned media. RNA were analyzed by Northern blotting; TP1 mRNA levels } \\
\text { were normalized to levels of } 28 \mathrm{SN} \text { RA. Values are the mean } \pm \text { S.E.M. of at least three } \\
\text { experiments and are expressed as a percentage of the value obtained with media } \\
\text { conditioned by Sertoli cells cultured in the absence of hormone. } \\
{ }^{*} P<0.05 \text { vs the corresponding control. }\end{array}$} \\
\hline
\end{tabular}

Henriksen et al. 1995, Marathe et al. 1995, El Shennawy et al. 1998), but some of them did not produce statistically significant results (Saito et al. 2000). Moreover, Henriksen et al. (1995) suggested an increase in apoptosis of PS of stage XII under testosterone stimulation. The difference in the proportion of apoptotic germinal cells in control compared with FSH plus testosterone-treated cultured cells was rather small when compared with the results of some in vivo data (Billig et al. 1995, Brinckworth et al. 1995, Henriksen et al. 1995, Marathe et al. 1995, El Shennawy et al. 1998); however, its amplitude was in the same range as that observed by Henriksen et al. (1996) when seminiferous tubular fragments from stages V-VIII were incubated for 3 days in the absence or presence of FSH. Hence, the present results indicate that the overall effect of treatment of the cocultures with FSH and/or testosterone cannot be related solely to the effect of these hormones on germ cell apoptosis. Indeed, the enhancement of the RS population in vitro by FSH was observed not only on the total number of RS per well (Fig. 1) but also when $1 \mathrm{C}$ cells were expressed as a proportion of the total population of germ cells (Table 2). This assumption is substantiated by the higher content of FSH-treated cultures in TP1 mRNAs (specific to the haploid state) without any significant modification by the hormones of the amounts of TH2B mRNAs (specific to pachytene spermatocytes). The rather small decrease of TH2B mRNAs between days 0 and 4, that is, at a time when the number of PS decreased more abruptly, can be explained by a maturation of PS in culture. Indeed, the proportion of middle PS, which express TH2B at the highest level (Marret et al. 1998), increases 1.5-fold during the first days of coculture, whereas that of early PS decreases 7-fold, with no change in the proportion of late PS (M.H. Perrard, unpublished results). The delay between the occurrence in PS-Sertoli cell cocultures of a $1 \mathrm{C}$ population, on one hand, and the increase in the amount of TP1 mRNA, on the other hand, can be explained on the basis that expression of TP1 appears to be more important from steps $5-6$ of spermiogenesis, that is, $4-5$ days after completion of meiosis (Marret et al. 1998). Since the PS seeded on Sertoli cells were mostly middle to late PS and neither hormone tested modified the half-life of RS in our cultures, it seems reasonable to conclude that $\mathrm{FSH}$ has a positive effect on the completion of the meiotic divisions. Testosterone also appears to be involved in the regulation of this step. Testosterone-treated cultures were usually intermediary between control and FSH-treated or FSH plus testosterone-treated cells, and a combination of testosterone and FSH was often more potent than FSH alone. These results extend in vivo data on the hormonal regulation of spermatogenesis in the adult or pubertal hypophysectomized rat (El Shennawy et al. 1998, França et al. 1998, Russell et al. 1998) and after long-term suppression of testosterone or both testosterone and FSH in the adult rat (Meachem et al. 1997, 1998, review in McLachlan et al. 2002). Indeed, these authors reported a role on cell viability for both $\mathrm{FSH}$ and testosterone at early stages of the meiotic cycle and suggested an overlapping and synergistic/additive effect of these 
hormones in this step. In addition, Parvinen and Ventela (1999) reported that the preferential action of FSH was associated with stages that involve meiotic divisions and early spermiogenesis. Nevertheless, even cultures maintained in the absence of these hormones maintained some capacity to support the meiotic divisions of middle/late pachytene spermatocytes. Since, as opposed to in vivo experiments, such a result cannot be explained by 'residual' concentrations of hormones, it suggests that most of the endocrine message for meiosis is acquired by the germinal cells around steps VI-VIII of the spermatogenic cycle (Toppari \& Parvinen 1985, Perrard et al. 2003) and/or that other local factor(s) originating from Sertoli cells can compensate for the absence of these hormones (see below).

Further support for an overlapping and additive effect of FSH and testosterone on some steps of spermatogenesis was gained from a different experimental approach in which RS were incubated with SCGM. The contents in TP1 mRNAs of RS incubated with medium from Sertoli cells cultured with either hormone were similar to, and higher than, those of spermatids incubated in control medium, but not different from those of freshly isolated round spermatids. Hence, it cannot be ascertained from these results whether such differences were due to an enhancement of transcription of these genes under the influence of hormone dependent-Sertoli cell-derived factors and/or to an inhibition of the degradation of these mRNAs. By contrast, the combination of FSH and testosterone resulted in an enhancement of the transcription of TP1. Indeed, the contents in TP1 mRNAs of spermatids incubated in medium from Sertoli cells cultured with both hormones were higher than those of spermatids incubated in control media but also from those of spermatids immediately after their isolation.

Since the Sertoli cells used in the present experiments were isolated from early pubertal animals and such cells have been shown to exhibit a different responsiveness to FSH and testosterone from Sertoli cells of adult animals (Griswold 1993, Sar et al. 1993), the question of how the effects observed in the present work relate to the physiologic situation in the adult could be raised. No definite answer can be given since coculture of adult Sertoli cells with PS cannot be maintained beyond a few days (M. Vigier \& Ph. Durand, unpublished data). However, it has been shown that in the hypophysectomized rat, FSH and/or testosterone prevent(s) germ cell loss during meiosis, in both pubertal (Russell et al. 1998) and adult (El Shennawy et al. 1998) animals. Moreover, we have observed that from day 4 of culture onward, Sertoli cells from 20-day-old rats respond to $\mathrm{FSH}$, in terms of cAMP production, like short-term-cultured Sertoli cells from mature (Clermont \& Perey 1957) 45-day-old animals (M. Vigier \& Ph. Durand, unpublished data). Besides, the present results fit rather well with a recent report using hypogonadal mice expressing transgenic FSH, alone or in combination with testosterone (Haywood et al. 2003). Indeed, these authors showed that FSH actions combine synergistically with androgens to have a marked effect on both meiotic and postmeiotic germ cell maturation.

It might be argued that the effects observed in culture are relatively minor. However, in view of the in vivo data reported in the literature, it appears that the amplitude of the short-term effects of either FSH or testosterone on the narrow step of spermatogenesis studied in the present study, is rather similar in vivo (Sinha Hikim \& Swerdloff 1995, El Shennawy et al. 1998, Meachem et al. 1999, O'Donnell et al. 1999, Saito et al. 2000) and in vitro (present results). In addition, it is becoming clearer that hormones and intratesticular regulatory factors may compensate, at least in part, for the absence of some hormones or factors, including FSH (Kumar et al. 1997, Dierich et al. 1998, Abel et al. 2000) and androgen (Yeh et al. 2002, Chang et al. 2004, De Gendt et al. 2004, Holdcraft \& Braun 2004), or luteinizing hormone (Zhang et al. 2003) receptors. Thus, it is likely that synergism and/or redundancy between regulatory molecules is a characteristic of the spermatogenic process, on which depends species survival. Hence, it is not unexpected that addition or removal of some hormone or factor, at least for a short time, either in vivo or in vitro, may have only a limited, although significant, effect on a given step of spermatogenesis.

It seems important to recall that even $\mathrm{KO}$ experiments for FSH (Kumar et al. 1997, Dierich et al. 1998, Abel et al. 2000) and androgen receptors in Sertoli cells (Chang et al. 2004, De Gendt et al. 2004, Holdcraft \& Braun 2004) have produced somewhat different results. This might indicate 
accumulative disorders throughout development in the different mouse models. Culture systems are not affected by such drawbacks, although indeed they remain in vitro models. Hence putting together results from $\mathrm{KO}$ experiments and in vitro data should help to approach again the physiologic role of these hormones in spermatogenesis.

In conclusion, these studies, performed in vitro, show that FSH and testosterone have positive and somewhat overlapping effects on the rat meiotic divisions and the postmeiotic expression of a germ cell-specific gene, which cannot be related solely to their ability to reduce germ cell apoptosis. Finally, use of this culture system should help to test the effect of any hormone or factor on those steps in order to understand better their regulation.

\section{Acknowledgements}

We are indebted to Professor K. Toshimori for providing us with the MN7 antibody. We thank Dr H. Lejeune and Dr M.-L. Delignette for assistance in statistical analysis, and A. M. Morera for discussion, as well as J. Bois and M.-A. Di Carlo for secretarial assistance. This work was supported by INSERM, INRA and the Université Claude-Bernard Lyon I.

\section{References}

Abel MH, Wootton AN, Wilkins V, Huhtaniemi I, Knight PG \& Charlton HM 2000 The effect of a null mutation in the

follicle-stimulating hormone receptor gene on mouse reproduction. Endocrinology 141 1795-1803.

Ahmad N, Haltmeyer GC \& Eik-Nes KS 1975 Maintenance of spermatogenesis with testosterone or dihydrotestosterone in hypophysectomized rats. Fournal of Reproduction and Fertility $\mathbf{4 4}$ 103-107.

Barbu V \& Dautry FF 1989 Northern blot normalization with 28S rRNA oligonucleotide probe Nucleic Acid Research 17 7115-7117.

Billig H, Furuta I, Rivier C, Tapanainen J, Parvinen M \& Hsueh AJW 1995 Apoptosis in testis germ cells: developmental changes in gonadotropin dependence and localization to selective tubule stages. Endocrinology 136 5-12.

Brinckworth MH, Weinbauer GF, Schlatt S \& Nieschlag E 1995 Identification of male germ cells undergoing apoptosis in adult rats. Fournal of Reproduction and Fertility 105 25-33.

Byers S, Jégou B, MacCalman C \& Blaschuk O 1993 Sertoli cell adhesion molecules and the collective organization of the testis. In The Sertoli Cell, pp 461-476. Eds LD Russell \& MD Griswold. Clearwater, FL: Cache River Press.

Chang C, Chen YT, Yeh SD, Xu Q, Wang RS, Guillou F, Lardy H \& Yeh S 2004 Infertility with defective spermatogenesis and hypotestosteronemia in male mice lacking the androgen receptor in Sertoli cells. PNAS $1016876-6881$.

Chomczynski P \& Sacchi N 1987 Single-step method of RNA isolation by acid guanidium thiocyanate-phenol-chloroform extraction. Analytical Biochemistry 162 152-159.

Clermont Y \& Perey B 1957 Quantitative study of the cell population of the seminiferous tubules in immature rats. American Fournal of Anatomy 100 241-267.

De Gendt K, Swinnen JV, Saunders PTK, Schoonjans L, Dewerchin M, Devos A, Tan K, Atanassova N, Claessens F, Lécureuil C, Heyns W, Carmeliet P, Guillou F, Sharpe RM \& Verhoeven G 2004 A Sertoli cell-selective knockout of the androgen receptor causes spermatogenic arrest in meiosis. PNAS 101 1327-1332.

Dierich A, Sairam MR, Monaco L, Fimia GM, Gansmuller A, LeMeur M \& Sassone-Corsi P 1998 Impairing follicle-stimulating hormone (FSH) signaling in vivo: targeted disruption of the FSH receptor leads to aberrant gametogenesis and hormonal imbalance. PNAS 95 13612-13617.

El Shennawy A, Gates RJ \& Russell LD 1998 Hormonal regulation of spermatogenesis in the hypophysectomized rat: cell viability after hormonal replacement in adults after intermediate periods of hypophysectomy. Fournal of Andrology 19 320-334.

França LR, Parreira GG, Gates RJ \& Russell LD 1998 Hormonal regulation of spermatogenesis in the hypophysectomized rat: quantitation of germ-cell population and effect of elimination of residual testosterone after long-term hypophysectomy. Fournal of Andrology 19 335-340.

Godet M., Damestoy A, Mouradian S, Rudkin B \& Durand P 2004 Key role for cyclin-dependent kinases in the first and second meiotic divisions of rat spermatocytes. Biology of Reproduction 70 $1147-1152$.

Godet M, Thomas A, Rudkin B \& Durand P 2000 Developmental changes in cyclin B1 and cyclin-dependent kinase 1 (CDK1) levels in the different populations of spermatogenic cells of the post-natal rat testis. European Fournal of Cell Biology 79 816-823.

Griswold MD 1993 Action of FSH on mammalian Sertoli cells. In The Sertoli Cell, pp 494-508. Eds LD Russell \& MD Griswold. Clearwater, FL: Cache River Press.

Haywood M, Spaliviero J, Jimenez M, King NJC, Handelsman DJ \& Allan CM 2003 Sertoli and germ cell development in hypogonadal (hpg) mice expressing transgenic follicle-stimulating hormone alone or in combination with testosterone. Endocrinology 44 509-517.

Henriksen K, Hakovirta H \& Parvinen M 1995 Testosterone inhibits and induces apoptosis in rat seminiferous tubules in a stage-specific manner: in situ quantification in squash preparations after administration of ethane dimethane sulfonate. Endocrinology 136 3285-3291.

Henriksen K, Kangasniemi M, Parvinen M, Kaipia A \& Hakovirta H 1996 In vitro, follicle-stimulating hormone prevents apoptosis and stimulates deoxyribonucleic acid synthesis in the rat seminiferous epithelium in a stage-specific fashion. Endocrinology 137 2141-2149.

Holdcraft RW \& Braun RE 2004 Androgen receptor function is required in Sertoli cells for the terminal differentiation of haploid spermatids. Development $131459-467$.

Hue D, Staub C, Perrard-Sapori MH, Weiss M, Nicolle JC, Vigier M \& Durand P 1998 Meiotic differentiation of germinal cells in three-week cultures of whole cell population from rat seminiferous tubules. Biology of Reproduction 59 379-387.

Kumar TR, Wang Y, Lu NF \& Matzuk MM 1997 Follicle stimulating hormone is required for ovarian follicle maturation but not male fertility. Nature Genetics 15 201-204.

Lee DR, Kaproth MT \& Parks JE 2001 In vitro production of haploid germ cells from fresh or frozen-thawed testicular cells of neonatal bulls. Biology of Reproduction 65 873-878.

Maddocks S \& Sharpe RM 1989 Dynamics of testosterone secretion by the rat testis: implications for measurement of the intratesticular levels of testosterone. Fournal of Endocrinology 122 323-329.

Marathe GK, Shetty J \& Dighe RR 1995 Selective 
immunoneutralization of luteinizing hormone results in the apoptotic cell death of pachytene spermatocytes and spermatids in the rat testis. Endocrine 3 705-709.

Marh J, Tres LL, Yamazaki Y, Yanagimachi R \& Kierszenbaum AL 2003 Mouse round spermatids developed in vitro from pre-existing spermatocytes can produce normal offspring by nuclear injection into in vivo developed mature oocytes. Biology of Reproduction 69 169-176.

Marret C, Avallet O, Perrard-Sapori MH \& Durand P 1998 Localization and quantitative expression of mRNAs encoding the testis-specific histone TH2B, the phosphoprotein p19, the transition proteins 1 and 2 during pubertal development and throughout the spermatogenic cycle of the rat. Molecular Reproduction and Development $\mathbf{5 1} 22-35$.

McLachlan RI, O'Donnell L, Meachem SJ, Stauton PG, deKretser DM, Pratis IC \& Robertson DM 2002 Identification of specific sites of hormonal regulation in spermatogenesis in rats, monkey and man. Recent Progress in Hormone Research 57 149-179.

McLachlan RI, Wreford NG, deKretser DM \& Robertson DM 1995 The effects of recombinant follicle-stimulating hormone on the restoration of spermatogenesis in the gonadotropin-releasing hormone-immunized adult rat. Endocrinology 136 4035-4043.

McLachlan RI, Wreford NG, Meachem SJ, deKretser DM \& Robertson DM 1994 Effects of testosterone on spermatogenic cell populations in the adult rat. Biology of Reproduction $\mathbf{5 1}$ 945-955.

Meachem SJ, McLachlan RI, Stanton PG, Robertson DM \& Wreford NG 1999 FSH immunoneutralisation acutely impairs spermatogonial development in normal adult rats. Fournal of Andrology 20 756-762.

Meachem SJ, Wreford NG, Robertson DM \& McLachlan RI 1997 Androgen action on the restoration of spermatogenesis in adult rats: effects of human chorionic gonadotrophin, testosterone and flutamide administration on germ cell number. International fournal of Andrology 20 70-79.

Meachem SJ, Wreford NG, Stanton PG, Robertson DM \& McLachlan RI 1998 Follicle-stimulating hormone is required for the initial phase of spermatogenic restoration in adult rats following gonadotropin suppression. Fournal of Andrology $\mathbf{1 9}$ 725-735.

O'Donnell L, Pratis K, Stanton PG, Robertson DM \& McLachlan RI 1999 Testosterone-dependent restoration of spermatogenesis in adult rats is impaired by a 5 alpha-reductase inhibitor. Fournal of Andrology 20 109-117.

Onoda M, Djakiew D \& Papadopoulos V 1991 Pachytene spermatocytes regulate the secretion of Sertoli cell protein(s) which stimulate Leydig cell steroidogenesis. Molecular and Cellular Endocrinology 77 207-216.

O'Shaughnessy PJ, Bennett MK, Scott IS \& Charlton HM 1992 Effects of FSH on Leydig cell morphology and function in the hypogonadal mouse. Fournal of Endocrinology 135 517-525.

Parvinen M \& Ventela S 1999 Local regulation of spermatogenesis: a living cell approach. Human Fertility 2 138-142.

Parvinen M, Wright WW, Phillips DM, Mather JP, Musto NA \& Bardin CW 1983 Spermatogenesis in vitro: completion of meiosis and early spermiogenesis. Endocrinology 112 1150-1152.

Penhoat A, Jaillard C \& Saez JM 1994 Regulation of bovine adrenal cell corticotropin receptor mRNA levels by corticotropin (ACTH) and angiotensin-II (A-II). Molecular and Cellular Endocrinology 103 R7-R10.

Perrard MH, Hue D, Staub C, LeVern Y, Kerboeuf D \& Durand P 2003 Development of the meiotic step in testes of pubertal rats: comparison between the in vivo situation and under in vitro conditions. Molecular Reproduction and Development 65 86-95.

Raff MC, Barres BA, Burne JF, Coles HS, Ishizaki Y \& Jacobson MD 1993 Programed cell death and the control of cell survival: lessons from the nervous system. Science 262 695-700.
Russell LD, Alger LE \& Nequin LG 1987 Hormonal control of pubertal spermatogenesis. Endocrinology 120 1615-1632.

Russell LD, Ettlin RA, Sinha Hikim AP \& Clegg ED 1990 Staging for laboratory species. In Histological and Histopathological Evaluation of the Testis, pp 62-118. Clearwater, FL: Cache River Press.

Russell LD, Kershaw M, Borg KE, El Shennawy A, Rulli SS, Gates RJ \& Calandra RS 1998 Hormonal regulation of spermatogenesis in the hypophysectomized rat: FSH maintenance of cellular viability during pubertal spermatogenesis. Fournal of Andrology 19 308-319.

Saito K, O'Donnell L, McLachlan RI \& Robertson DM 2000 Spermiation failure is a major contributor to early spermatogenic suppression caused by hormone withdrawal in adult rats. Endocrinology $1412779-2785$.

Sar M, Hall SH, Wilson EM \& French FS 1993 Androgen regulation of Sertoli cells. In The Sertoli Cell, pp 509-516. Eds LD Russell \& MD Griswold. Clearwater, FL: Cache River Press.

Sharpe RM 1994 Regulation of spermatogenesis. In The Physiology of Reproduction, 2nd edn, pp 1363-1434. Eds E Knobil \& JD Neill. New York: Raven Press.

Shetty J, Marathe GK \& Dighe RR 1996 Specific immunoneutralization of FSH leads to apoptotic cell death of the pachytene spermatocytes and spermatogonial cells in the rat. Endocrinology 137 2179-2182.

Sinha Hikim AP \& Swerdloff RS 1993 Temporal and stage-specific changes in spermatogenesis of rat after gonadotropin deprivation by a potent gonadotropin-releasing hormone antagonist treatment. Endocrinology 133 2161-2170.

Sinha Hikim AP \& Swerdloff RS 1995 Temporal and stage-specific effects of recombinant human follicle-stimulating hormone on the maintenance of spermatogenesis in gonadotropin-releasing hormone antagonist-treated rat. Endocrinology 136 253-261.

Sousa M, Cremades N, Alves C, Silva J \& Barros A 2002 Developmental potential of human spermatogenic cells co-cultured with Sertoli cells. Human Reproduction 217 161-172.

Staub C, Hue D, Nicolle JC, Perrard-Sapori MH, Segretain D \& Durand P 2000 The whole meiotic process can occur in vitro in untransformed rat spermatogenic cells. Experimental Cell Research $26085-95$.

Tanii I, Araki S \& Toshimori K 1994 Intra-acrosomal organization of a 90-kilodalton antigen during spermiogenesis in the rat. Cell and Tissue Research 277 61-67.

Toppari J \& Parvinen M 1985 In vitro differentiation of rat seminiferous tubular segments from defined stages of the epithelial cycle morphologic and immunolocalization analysis. Fournal of Andrology 6 334-343.

Weiss M, Vigier M, Hue D, Perrard-Sapori MH, Marret C, Avallet O \& Durand P 1997 Pre- and post-meiotic expression of male germ cell specific genes throughout 2-week cocultures of germinal and Sertoli cells. Biology of Reproduction 57 68-76.

Yeh S, Tsai MY, Xu Q, Mu XM, Lardy H, Huang KE, Lin H, Yeh SD, Altuwaijri S, Zhou X, Xing L, Boyce BF, Hung MC, Zhang S, Gan L \& Chang C 2002 Generation and characterization of androgen receptor knockout (ARKO) mice: an in vivo model for the study of androgen functions in selective tissues. PNAS 99 13498-13503.

Zhang FP, Pakarainen T, Pontanen M, Toppari J \& Huhtaniemi I 2003 The low gonadotropin-independent constitutive production of testicular testosterone is sufficient to maintain spermatogenesis. PNAS $10013692-13697$.

\section{Received in final form 16 June 2004 Accepted 18 August 2004 Made available online as an Accepted Preprint 1 September 2004}

